\title{
EDITORIAL
}

\section{CALEIDOSCÓPIO, TRADUÇÃO E PRODUÇÃO CIENTÍFICA}

\author{
Ana Helena Rossi ${ }^{1}$ \\ Universidade de Brasília, Brasil \\ anahrossi@gmail.com
}

\section{DOI: https://doi.org/10.26512/caleidoscopio.v4i2.37859}

Com muito prazer e satisfação apresento mais um número da revista caleidoscópio: literatura e tradução, que vê o dia em 2021. Nesse momento aterrador de pandemia que assola nosso país, esse editorial é um sinal de força para seguirmos com nossas atividades com ética e profundidade. Agora é a hora! Assim, a revista caleidoscópio: literatura e tradução posiciona-se de maneira contundente e com imenso respeito no que concerne ao momento de infinita dor para muitos dos nossos contemporâneos em razão de suas perdas. A hora é de CUIDAR para seguirmos com determinação e carinho para com o que fazemos.

Nesse sentido, tenho a honra de iniciar o Editorial do volume 4, número 2 com a seção Artes que apresenta seis textos poéticos. Embora o adjetivo “poético" seja o denominador comum para reuni-los, trata-se de textos fundamentalmente diferentes entre si, tanto no que diz respeito às temáticas colocadas em cena, como também pelo tipo de escrita. Nessa linha de pensamento, são textos densos, finamente lapidados que dão conta da imensidão interpretativa que todo texto pode assumir em sua infinitude. Com a seção Artes, a revista caleidoscópio: literatura e tradução confirma sua posição de acolher textos artísticos que também dizem alguma coisa sobre a realidade.

A seção Artigos apresenta cinco artigos que trazem à luz do dia problemáticas que permeiam o campo de conhecimento dos Estudos da Tradução/Tradutologia. De maneira brilhante, o artigo "À la recherche d'une traduction parfaite", de Oleg Almeida, discute as escolhas tradutórias de seis traduções, diacronicamente apresentadas, do poema "Le Prophète" de Alexandre Pouchkine, a partir de uma indagação que o autor qualifica como sendo o dilema "precisão versus inspiração". O segundo artigo intitulado "Quem fala

\footnotetext{
${ }^{1}$ Profa. Dra. Ana Helena Rossi. Editora-chefe da revista caleidoscópio: literatura e tradução. Atua no Departamento de Línguas Estrangeiras e Tradução (LET) do Instituto de Letras, e nos Programas de pósgraduação POSTRAD e POSLIT da Universidade de Brasília.
} 
Trasianka? Tradução e hibridismo linguístico em Belarus", de Paterson Franco e Jorge Hernán Yerro, propõe uma reflexão sobre a tradução da linguagem híbrida belarussorussa a partir da tradução e legendagem do filme Viva Belarus (2012). 0 terceiro artigo, intitulado "A mensagem de Clarice Lispector: tradução, léxico, simbolismos e suas interfaces com a psicologia analítica junguiana”, de Celso Fernando Rocha e Talita Serpa, se propõe de descrever o léxico de maior chavicidade no conto A mensagem de Clarice Lispector, no âmbito de uma perspectiva de tradução para o inglês. 0 quarto artigo, intitulado "O humor do sapateiro da peça Júlio César em tradução anotada e comentada", de Tiago Marques Luis e Lucilia Teodora Villela de Leitgeb Lourenço, propõe uma tradução comentada e anotada da peça trágica Júlio César, a partir de uma articulação entre os Estudos da Tradução e os Estudos Shakesperianos, tendo em vista a dupla natureza da tradução dos textos shakespearianos que ora são destinados a impressão, ora ao palco. 0 quinto artigo, intitulado "Queers e tradução: como traduzir? Visibilidade por meio da tradução", de Camila Cristina dos Santos e Pablo Simpson Kilzer Amorim, ao trazer questões de gênero e sexualidade, discute, por meio das falas das drag queens do reality show Rupaul's Drag Race, se as legendas em português mantêm o vocabulário queer.

A seção Traduções acolhe, com muita satisfação, duas traduções. Cabe aqui uma justa reflexão da revista caleidoscópio: literatura e tradução a respeito da produção científica. Por muitas submissões apresentarem propostas de tradução de línguas consideradas "exóticas" (a primeira tradução abaixo constitui um exemplo disso), a caleidoscópio: literatura e tradução iniciou um largo trabalho de identificação de especialistas destas línguas no Brasil no intuito de avaliar os trabalhos. Assim, hoje, temos uma ideia mais clara sobre a pesquisa no Brasil referente aos estudos que problematizam a tradução. Isso reforça a importância das revistas acadêmico-científicas como locus de identificação da pesquisa científica.

Assim, a primeira tradução apresenta o conto "0 irmão mais velho" do escritor Munhsi Premchand (1880 - 1936), do hindi para o português, Gisele Cardoso de Lemos. É uma excelente ocasião para alargarmos a reflexão integrando um universo cultural complexo e eminentemente diferente do nosso, além de integrar questões linguísticohistóricas - como, nesse caso, as decisões tradutórias referentes ao alfabeto devanagari no qual não há distinção entre letras maiúsculas e minúsculas - que permeiam a tradução, 
e que são problematizadas no projeto de tradução pela tradutora. Nessa idêntica linha de raciocínio, a segunda tradução, de Elys Regina Zils e Mary Anne Warken, consistiu em traduzir do castelhano para o português brasileiro o prefácio de Kirigirisu Haikús, obra com seleções e versões de Haicais japoneses traduzidos por Andrés Claro, trazendo à luz do dia questões de musicalidade no âmbito de uma reconstrução da oralidade, e o interesse pelas representações de mundo no texto poético.

Boa leitura! 